\title{
Morphological and morphometric characteristics, drying rate, and chemical composition of forage grasses grown for hay production
}

\section{Caracterização morfológica, desidratação e composição química de gramíneas forrageiras para produção de feno}

\author{
Keuven dos Santos Nascimento ${ }^{1 *}$; Ricardo Loiola Edvan ${ }^{2}$; Francigefeson Linhares \\ dos Santos Ezequiel ${ }^{3}$; Felipe Luênio de Azevedo ${ }^{3}$; Lucas de Souza Barros ${ }^{4}$; Marcos \\ Jácome de Araújo $^{2}$; Leilson Rocha Bezerra ${ }^{5}$; Daniel Biagiotti ${ }^{6}$
}

\section{Highlights:}

Massai grass has great potential for hay production.

Higher leaf to stem ratio in grasses increases the potential for hay production.

Reduction of crude protein in dehydration for hay production depends on the species.

\begin{abstract}
The objective of this study is to characterize six forage grass cultivars used for hay production. The morphological and morphometric characteristics of these cultivars were determined using a completely randomized block design, and the rates of loss of dry matter and crude protein $(\mathrm{CP})$ were evaluated using a completely randomized design with a 6 x 5 factorial scheme (six cultivars vs. five drying periods $[0,1,2,3$ and 4 hours $])$ and three repetitions. Morphological and morphometric characteristics and the chemical composition of the cultivars were analyzed using the Scott-Knott test, and the drying time was assessed using linear regression analysis at a level of significance of 5\%. There was a significant effect $(\mathrm{p}<0.05)$ of morphological and morphometric characteristics, except for stem thickness $(\mathrm{p}=0.1)$ and the live-to-dead biomass ratio $(\mathrm{p}=0.27)$. The Massai cultivar presented a higher leaf to stem ratio $(1.23$ $\pm 0.60)$. There was an increased linear response $(p<0.05)$ for the rate of water loss in the six evaluated cultivars. The Massai cultivar had a safe storage moisture content ( $80 \%$ dry matter) after 3 hours and 11 minutes of sun exposure, and the drying rate was $10.34 \%$ per hour of sun exposure. The cultivars Paredão and Marandú showed a decreasing linear effect of $\mathrm{CP}$ content across the harvest period, corresponding to $22.07 \%$ and $21.38 \pm 0.55 \%$ in fresh plants, respectively, and $20.13 \%$ and $18.11 \pm 0.55 \%$ after 4 hours of sun exposure, respectively. The Massai cultivar had the most efficient rate of water loss, reaching a safe storage moisture content in 3 hours and 6 minutes, with a CP content of $18.63 \%$.
\end{abstract}

Key words: Conservation. Drought. Hay-making. Forage.

\footnotetext{
1 Mestre em zootecnia, Universidade Federal do Piauí, UFPI, Bom Jesus, PI, Brasil. E-mail: keuvensantos03@gmail.com

2 Profs., UFPI, Campus Profa. Cinobelina Elvas, Bom Jesus, PI, Brasil. E-mail: edvan@ufpi.edu.br; jacome@ufpi.edu.br

3 Discentes do Curso de Mestrado do Programa de Pós-Graduação em Ciência Animal, PPGCA, Universidade Federal de Campina Grande, UFCG, Patos, PB, Brasil. E-mail: gefesson_linhares@hotmail.com; felipe.luenio19@gmail.com

4 Discente do Curso de Graduação em Zootecnia, UFPI, Bom Jesus, PI, Brasil. E-mail: lucas-souza16@hotmail.com

5 Prof., UFCG, Campus Patos, Patos, PB, Brasil. E-mail: leilson@ufpi.edu.br

6 Prof., UFPI, Colégio Técnico de Bom Jesus, Bom Jesus, PI, Brasil. E-mail: biagiotti@ufpi.edu.br

* Author for correspondence
} 


\section{Resumo}

Este trabalho objetiva a caracterização de seis cultivares de gramíneas forrageiras para a produção de feno. Na determinação dos componentes morfológicos e morfométricos dos seis cultivares de gramíneas forrageiras foi utilizado delineamento inteiramente casualizado, e para curva de desidratação da matéria seca e da perda de proteína bruta utilizou-se delineamento inteiramente casualizado em esquema fatorial $6 \times 5$, onde os fatores corresponderam aos seis cultivares e cinco tempos de desidratação $(0,1,2,3$ e 4 horas), ambos utilizaram três repetições. Para análise dos dados das características morfogênicas, morfométricas e composição química dos cultivares foi utilizado o teste de Scott Knott e para análise no tempo de desidratação foi utilizado análise de regressão linear, todos a $5 \%$ de probabilidade. Houve efeito significativo $(\mathrm{P}<0,05)$ para as análises morfométricas e morfológicas, exceto para as variáveis espessura de colmo $(\mathrm{EC})(\mathrm{P}=0,1)$ e relação matéria verde/matéria morta $(\mathrm{P}=0,27)$. Para relação lâmina

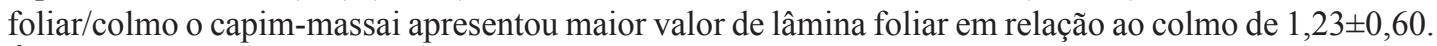
É possível observar resposta linear crescente $(\mathrm{p}<0,05)$ para curva de desidratação dos 6 cultivares estudados neste experimento. O capim-massai atingiu ponto de feno ( $80 \%$ matéria seca) após 3 horas e 11 minutos de exposição ao sol, e taxa de desidratação com aumento de $10,34 \%$ de matéria seca por hora. Em relação ao teor de proteína bruta $(\mathrm{PB})$ na desidratação, os capins paredão e marandú apresentam efeito linear decrescente para os períodos de coleta, onde o material in natura apresentaram 22,07 e $21,38 \pm 0,55 \%$ e após 4 horas de exposição ao sol apresentaram 20,13 e $18,11 \pm 0,55 \%$ respectivamente. $\mathrm{O}$ capim-massai foi o mais eficiente para desidratação, atingindo o ponto de feno em 3 horas e 6 minutos, com teor de PB de $18,63 \%$.

Palavras-chave: Conservação. Estiagem. Fenação. Forragem.

\section{Introduction}

Tropical regions have a significant potential for animal breeding because of the diversity of natural resources and climatic characteristics, which allow high yields during the rainy season. Furthermore, high rainfall and high temperatures increase the productive potential of forage plants (Ribeiro et al., 2014). However, in dry seasons, the lack of highquality food combined with the lack of food planning for herds causes producers to seek alternative feed sources during this period (Oliveira et al., 2016), increasing the cost of production.

Given the seasonality of forage production, food conservation techniques are necessary during the off-season to provide an adequate food supply during the dry season (Queiroz et al., 2012). Therefore, the application of techniques such as hay-making and/ or ensiling increases food security for herds in this region.

Harvesting and storing excess forage with a high nutritional value during the period of higher abundance and using this material in the off-season as feed in the form of hay is an alternative to reduce food shortage (D. J. Ferreira et al., 2014). Haymaking preserves food quality, allowing animal weight gain during the dry period (Pereira, Lima, Assis, \& Emerenciano, 2018).

In the haying-making process, it is essential to consider the ideal time for forage harvest and the factors that promote losses (Pinho et al., 2013). The conversion of the nutritional value of forage by rapid water loss reduces excess moisture and increases product stability because the respiratory activity of plants and microorganisms is inhibited (Calixto, Jobim, Cecato, Santos, \& Bumbieris, 2012). The faster is dehydration, the more efficient is haymaking, reducing the loss of nutrients from forage plants and increasing feed quality. Morphological characteristics affect hay quality by impacting the dehydration of forage species.

Studies with different cultivars allow identifying plant cultivars with the highest potential for hay-making because the drying rate may vary according to the morphological and morphometric characteristics of the forage, which affects the rate 
of water loss and dry matter (DM) content (Neres et al., 2011), and consequently the nutritional quality of the forage.

Therefore, it is critical to know the characteristics of forage cultivars with the potential for haymaking. The objective of this study is to evaluate the morphological characteristics, rates of water loss, and chemical composition of six grass cultivars used for hay production.

\section{Material and Methods}

The experiment was conducted in the city of Bom Jesus, Piauí, Brazil. Bom Jesus (latitude, 0904'28' $\mathrm{S}$; longitude, $44^{\circ} 21^{\prime} 31^{\prime \prime} \mathrm{W}$; altitude, 277 meters) is located to the south of the state of Piauí, in the microregion of Upper Gurguéia. The climate of the region is classified as BSh, according to Köppen's classification (1936), with wet summer and dry winter, minimum temperature of $18{ }^{\circ} \mathrm{C}$, maximum temperature of $36^{\circ} \mathrm{C}$, and an average annual rainfall of $900 \mathrm{~mm}$ (Alvares et al., 2013).

Morphological and morphometric characteristics were analyzed using a completely randomized block design with six treatments corresponding to different forage grass cultivars: signal grass (Brachiaria brizantha var. Marandú and Xaraés), guinea grass (Panicum maximus var. Massai and Paredão), and gamba grass (Andropogon gayanus var. Planaltina and Tupã), with three repetitions.

The cultivars were randomly collected from an area established in 2016. The soil was classified as Dystrophic Yellow Latosol, with a sandy clay loam texture (clay, $257 \mathrm{~g} \mathrm{~kg}^{-1}$; silt, $34 \mathrm{~g} \mathrm{~kg}^{-1}$, sand, 709 $\mathrm{g} \mathrm{kg}^{-1}$ ) and presented the following characteristics: $\mathrm{pH}$ in water, 5.5; phosphorus, $74.5 \mathrm{mg} \mathrm{dm}^{-3}$; potassium, $127.0 \mathrm{mg} \mathrm{dm}^{-3}$; calcium, $1.68 \mathrm{cmol}_{\mathrm{c}} \mathrm{dm}^{-}$ 3; magnesium, $0.77 \mathrm{cmol}_{\mathrm{c}} \mathrm{dm}^{-3}$; aluminum, $<0.00$ $\mathrm{cmol}_{\mathrm{c}} \mathrm{dm}^{-3}$; hydrogen + aluminum, $1.94 \mathrm{cmol}_{\mathrm{c}}$ $\mathrm{dm}^{-3}$; base sum, $2.78 \mathrm{cmol}_{\mathrm{c}} \mathrm{dm}^{-3}$; cation exchange capacity at $\mathrm{pH} 7.0,4.72 \mathrm{cmol}_{\mathrm{c}} \mathrm{dm}^{-3}$; base saturation, $59 \%$; and aluminum saturation, $0.00 \%$.
For grass cultivation, soil correction was performed using $30 \mathrm{~kg} \mathrm{ha}^{-1}$ potassium (potassium chloride) and $45 \mathrm{~kg} \mathrm{ha}^{-1}$ phosphorus (single superphosphate) according to the results of soil analysis. During each productive cycle (25 days), the cultivars were fertilized with nitrogen (urea) at a dose of $150 \mathrm{~kg}$ of $\mathrm{N} \mathrm{ha}^{-1}$, and this dose was divided according to the production cycles throughout the year and was repeated as necessary. The study site was irrigated with a water level equivalent to $5 \mathrm{~mm}$ per day using a sprinkler system.

Samples were collected on May 10, 2019, with an interval of 25 days since the last harvest for all cultivars in the study site. Pruning shears were used to cut the plants. After cutting, a $500 \mathrm{~g}$ sample was collected, and the following morphological characteristics were analyzed: number of fully expanded leaves (NFEL) considering the leaves with externalized ligule; leaf to stem ratio (LSR), obtained by dividing the DM of the leaves by the DM of the stem and sheath; live-to-dead biomass ratio (LDB), obtained by dividing the DM of live biomass by the DM of dead biomass. DM was measured on a digital electronic scale model Sf-400 $\left(\mathrm{UNICASA}^{\circledR}\right.$ ) with a capacity of $1 \mathrm{~g}$ to $5 \mathrm{~kg}$.

The following morphometric characteristics were evaluated in three tillers: leaf thickness (LT); stem thickness (ST), measured using a digital caliper with an accuracy of $0.05 \mathrm{~mm}$; leaf width (LW), measured from one end of the leaf to the other end using a tape measure graduated in centimeters; leaf length (LL), by measuring the leaf blade longitudinally using a tape measure graduated in centimeter; and stem length (SL), measured from the base of the stem to the apex.

The drying curve for DM and loss of crude protein $(\mathrm{CP})$ during drying were evaluated using a completely randomized block design in a $6 \times 5$ factorial scheme (six forage grass cultivars and five drying times $[0,1,2,3$, and $4 \mathrm{~h}]$ ), with three repetitions. 
For hay production, the cultivars were cut at a pre-established height, according to the recommendations of Fonseca and Martuscello (2010). The cuts were made at the height of 15 $\mathrm{cm}$ for the varieties Marandú, Xaraés, and Massai and at the height of $30 \mathrm{~cm}$ for the cultivars Tupã, Planaltina, and Paredão. The cuts were performed in the early hours of the day to improve drying efficiency. The cut forage was immediately exposed to the sun.

Data on weather conditions during the time of forage harvesting until hay baling were collected at the Bom Jesus Automatic Meteorological Station from the National Institute of Meteorology (Instituto Nacional de Meteorologia [IMET], 2019) (Table 1).

Table 1

Average temperature $\left({ }^{\circ} \mathrm{C}\right)$, average humidity $(\%)$, precipitation $(\mathrm{mm})$, radiation $\left(\mathrm{Kj} / \mathrm{m}^{2}\right)$, and wind speed $(\mathrm{m} / \mathrm{s})$ in the morning and afternoon on May 10, 2019, in Bom Jesus, Piauí, Brazil

\begin{tabular}{|c|c|c|c|c|c|}
\hline \multirow{2}{*}{ Period } & Temperature & Humidity & Wind speed & Radiation & Precipitation \\
\hline & $\left({ }^{\circ} \mathrm{C}\right)$ & $(\%)$ & $(\mathrm{m} / \mathrm{s})$ & $\left(\mathrm{kJ} / \mathrm{m}^{2}\right)$ & $(\mathrm{mm})$ \\
\hline Morning (maximum) & 24.23 & 80.86 & & & \\
\hline Morning (minimum) & 22.44 & 73.29 & 2.70 & 413.37 & 0.00 \\
\hline Afternoon (maximum) & 34.05 & 42.83 & 7.28 & 2366.83 & 0.00 \\
\hline Afternoon (minimum) & 31.93 & 36.50 & & & \\
\hline
\end{tabular}

Instituto Nacional de Meteorologia (2019), Bom Jesus Station. WMO Code: 81987.

The samples were exposed to the sun on a plastic tarp and turned every $30 \mathrm{~min}$ to standardize and accelerate dehydration. To evaluate the rate of water loss of the cultivars, the time of harvest was considered as zero hour, and subsequent harvests were performed every $1 \mathrm{~h}$ during $4 \mathrm{~h}$. The cut forage was weighed and pre-dried in a forced ventilation oven at $60^{\circ} \mathrm{C}$ until it reached constant weight.

The measurement of DM (Method INCT-CA G-003/1) and CP (Method INCT-CA N-001/1) was performed at the Animal Nutrition Laboratory (Laboratorio de Nutricao Animal-LANA) of UFPI using the methodologies described by Detmann et al. (2012).

The data were subjected to analysis of variance, and the average morphological and morphometric characteristics and chemical composition of the cultivars were compared using the Scott-Knott test at a level of significance of $5 \%$. Data on the drying curves and loss of CP as a function of the drying time were subjected to linear regression analysis at a level of significance of 5\% using SISVAR software version 5.3 (D. F. Ferreira, 2011).

\section{Results and Discussion}

There was a significant effect $(\mathrm{P}<0.05)$ of the morphometric characteristics of the cultivars, except for ST $(\mathrm{p}=0.1)$, and LDB $(\mathrm{p}=0.27)$.

There was a significant difference $(\mathrm{p}=0.01)$ in NFEL among the cultivars, and Andropogon gayanus cultivars presented higher values, followed by Marandú, with 4.16, 4.00, and $3.83 \pm 0.43 \mathrm{~cm}$, respectively (Table 2). The differences in NFEL can be explained by the dependence of this variable on the level of organic reserves of the plant due to the initial leaf area development (Haddade et al., 2005), which depends on plant genetics.

During plant development, the development of new leaves exceeds the rate of leaf expansion, i.e., NFEL is higher than the number of emerging leaves (Parsons, Johnson, \& Williams, 1988). This 
characteristic improves the nutritional quality of hay in developing plants when compared to plants with a higher NFEL because the stage of maturity affects the concentration of cellular components and the nutritional value of the forage, resulting in lower-quality hay (Oliveira et al., 2016). This finding is corroborated by Haddade et al. (2005) in elephant grass (Pennisetum purpureum), in which NFEL was decreased as the total number of leaves was increased.

Table 2

Morphological and morphometric characteristics of forage grass cultivars used for hay production

\begin{tabular}{lcccccccc}
\hline \multirow{2}{*}{ Cultivar } & \multicolumn{4}{c}{ Morphometric } & \multicolumn{3}{c}{ Morphological } \\
\cline { 2 - 9 } & LW & LL & SL & LT & ST & NFEL & LDB & LSR \\
\hline Marandú & $1.0 \mathrm{~B}$ & $18.55 \mathrm{~B}$ & $19.33 \mathrm{C}$ & $0.39 \mathrm{~B}$ & 2.22 & $3.83 \mathrm{~A}$ & 3.66 & $0.88 \mathrm{C}$ \\
Xaraés & $2.08 \mathrm{~A}$ & $39.06 \mathrm{~A}$ & $22.91 \mathrm{C}$ & $0.49 \mathrm{~A}$ & 3.15 & $2.50 \mathrm{~B}$ & 3.83 & $1.02 \mathrm{~B}$ \\
Massai & $0.64 \mathrm{~B}$ & $40.93 \mathrm{~A}$ & $15.30 \mathrm{C}$ & $0.62 \mathrm{~A}$ & 3.95 & $2.0 \mathrm{~B}$ & 3.33 & $1.23 \mathrm{~A}$ \\
Paredão & $1.71 \mathrm{~A}$ & $41.74 \mathrm{~A}$ & $20.50 \mathrm{C}$ & $0.50 \mathrm{a}$ & 3.34 & $2.16 \mathrm{~b}$ & 3.50 & $0.89 \mathrm{C}$ \\
Planaltina & $0.90 \mathrm{~B}$ & $25.58 \mathrm{~B}$ & $74.08 \mathrm{~A}$ & $0.26 \mathrm{~B}$ & 2.81 & $4.0 \mathrm{~A}$ & 4.83 & $0.68 \mathrm{D}$ \\
Tupã & $0.84 \mathrm{~B}$ & $28.25 \mathrm{~B}$ & $49.50 \mathrm{~B}$ & $0.36 \mathrm{~B}$ & 2.89 & $4.16 \mathrm{~A}$ & 4.39 & $0.26 \mathrm{D}$ \\
\hline SEM & 0.18 & 4.02 & 3.23 & 0.05 & 0.26 & 0.43 & 0.46 & 0.60 \\
P-value & $<0.01$ & $<0.01$ & $<0.01$ & 0.01 & 0.10 & 0.01 & 0.27 & $<0.01$ \\
\hline
\end{tabular}

LW, leaf width (cm); LL, leaf length (cm); SL, stem length (cm); LT, leaf thickness (mm); ST, stem thickness (mm); NFEL, number of fully expanded leaves; LDB, live-to-dead biomass ratio (g); LSR, leaf to stem ratio; SEM, standard error of the mean. Values followed by the same letter in each column were not significantly different from each other using the Scott-Knott test at a level of significance of $5 \%$.

There were significant differences $(p<0.01)$ in the LSR, and the Massai cultivar presented the highest ratio $(1.23 \pm 0.60)$. The higher number of leaves of this cultivar was associated with shorter SL $(15.30 \pm 3.23 \mathrm{~cm})$, corroborating the results of Silva et al. (2011) in Tanzania grass. Dantas and Negrão (2010) have shown that the best grass hay has a higher LSR. The leaves are more quickly dried in full sun and reach a safe storage moisture content when weather conditions are favorable.

There was a significant effect of the variables LW $(p<0.01)$, LL $(p<0.01)$, and LT $(p=0.01)$ among the cultivars, especially for Xaraés and Paredão, which presented LW of 2.08 and $1.71 \pm 0.18 \mathrm{~cm}$, LL of 39.06 and $41.74 \pm 4.02 \mathrm{~cm}$, and LT 0.49 and $0.50 \pm 0.05 \mathrm{~mm}$, respectively. This result was due to the morphological structure of these cultivars, characterized by broad, hairy leaves, and thicker central veins (Fonseca \& Martuscello, 2010). There was no significant effect of these variables considering the lowest averages for the cultivars Marandú, Planaltina, and Tupã, which is an advantage for hay production because narrow leaves have better drying potential under natural conditions (Neres \& Ames, 2015).

There was a significant effect $(\mathrm{p}<0.01)$ of $\mathrm{SL}$ in Andropogon gayanus, with average values of 74.08 and $49.50 \pm 3.23 \mathrm{~cm}$, for the cultivars Planaltina and Tupã, respectively. The degree of maturity affected this characteristic because flowering in these cultivars occurred earlier than in the other cultivars, even at 25 days.

There was no significant effect of hay DM between cultivars at $\mathrm{H} 0$. This result is due to the fact that forage was harvested immediately after cutting for all cultivars, and the cutting cycle and rest 
period was the same for all cultivars. This approach allowed obtaining a DM content (in fresh plants) of $32.0-36.7 \pm 1.29 \%$ (Table 3).

There was an increasing linear response $(\mathrm{p}<0.05)$ for the drying curve in the six cultivars. However, the cultivars Marandú, Xaraés, Planaltina, and Tupã did not reach a safe storage moisture content during the study period. This result is due to the limitations in the growth of the genus Brachiaria because of its higher ST, which increases the drying period of the plant (Neres et al., 2010). The Andropogon gayanus cultivars presented higher reproductive precocity than the other forage grasses, and higher SL, which resulted in the longest dehydration period.

Table 3

Dry matter content $(\%)$ of forage grass cultivars according to the drying time in full sun

\begin{tabular}{|c|c|c|c|c|c|c|c|c|}
\hline \multirow{2}{*}{ Cultivar } & \multicolumn{6}{|c|}{ Time points (hours) } & \multirow{2}{*}{ Equation } & \multirow{2}{*}{ P-value } \\
\hline & H0 & H1 & $\mathrm{H} 2$ & H3 & $\mathrm{H} 4$ & $\mathrm{R}^{2}(\%)$ & & \\
\hline Marandú & 32.0 & $42.2 \mathrm{C}$ & $52.4 \mathrm{~B}$ & $62.7 \mathrm{~B}$ & $72.9 \mathrm{C}$ & 99,6 & $\mathrm{Y}=32.01+10.23 \mathrm{H}$ & $<0.01$ \\
\hline Xaraés & 32.7 & $42.8 \mathrm{~B}$ & $53.0 \mathrm{~B}$ & $63.1 \mathrm{~B}$ & $73.2 \mathrm{C}$ & 98.8 & $\mathrm{Y}=32.72+10.13 \mathrm{H}$ & $<0.01$ \\
\hline Massai & 38.4 & $51.7 \mathrm{~A}$ & $65.1 \mathrm{~A}$ & $78.4 \mathrm{~A}$ & $91.8 \mathrm{~A}$ & 96.6 & $\mathrm{Y}=38.43+13.34 \mathrm{H}$ & $<0.01$ \\
\hline Paredão & 36.0 & $47.2 \mathrm{~A}$ & $58.3 \mathrm{~A}$ & $69.4 \mathrm{~B}$ & $80.5 \mathrm{~B}$ & 92.7 & $\mathrm{Y}=36.09+11.11 \mathrm{H}$ & $<0.01$ \\
\hline Planaltina & 33.7 & $44.2 \mathrm{~B}$ & $54.7 \mathrm{~B}$ & $65.2 \mathrm{~B}$ & $75.7 \mathrm{C}$ & 98.6 & $\mathrm{Y}=33.76+10.49 \mathrm{H}$ & $<0.01$ \\
\hline Tupã & 36.7 & $45.4 \mathrm{~B}$ & $54.1 \mathrm{~B}$ & $62.8 \mathrm{~B}$ & $71.4 \mathrm{D}$ & 96.9 & $\mathrm{Y}=36.78+8.67 \mathrm{H}$ & $<0.01$ \\
\hline SEM & & & 1.29 & & & & & \\
\hline P-value & & & $<0.01$ & & & & & \\
\hline
\end{tabular}

SEM: standard error of the mean. Values followed by the same letter in each column were not significantly different from each other using the Scott-Knott test at a level of significance of $5 \%$. * significant at $\mathrm{p}<0.05$ for the linear effect; ns, not significant at $\mathrm{p}<0.05$ for the linear effect.

Calixto et al. (2012) found that hay-making consisted of decreasing forage moisture to values below $20 \%$ and obtaining a DM of $80 \%$, allowing safe storage of hay and low rates of loss of CP. Therefore, the Massai cultivar presented the highest drying efficiency, reaching a safe storage moisture content after $3 \mathrm{~h}$ and $6 \mathrm{~min}$ of sun exposure. This result was mainly due to the high LSR because a higher number of leaves relative to stems accelerates dehydration. The DM content of the varieties Paredão, Planaltina, Xaraés, Marandú, and Tupã at the time of cutting was $36.0 \%, 33.7 \%$, $32.7 \%, 32.0 \%$, and $36.7 \%$, respectively, and these varieties reached a safe storage moisture content at $3 \mathrm{~h}$ and $56 \mathrm{~min}, 4 \mathrm{~h}$ and $24 \mathrm{~min}, 4 \mathrm{~h}$ and $39 \mathrm{~min}, 4$ $\mathrm{h}$ and $40 \mathrm{~min}$, and $4 \mathrm{~h}$ and $58 \mathrm{~min}$ of sun exposure, respectively.
The cultivar Paredão presented the second highest rate of water loss and reached a safe storage moisture content at $3 \mathrm{~h}$ and $56 \mathrm{~min}$. This result is due to its morphological and morphometric characteristics, with a high LDB, and shorter SL, which increases drying because of the lower immobilization of water molecules in the stem. Jobim, Nussio, Reis, and Schmidt (2007) have shown that stems contain more water than leaves and the whole plant at the time of cutting, and the stem is more resistant to dehydration.

Zanine and Diniz (2006) reported that hay could deteriorate during drying under field conditions; therefore, rapid water loss is essential to maintain the quality of forage. Climatic conditions were favorable for drying during the hay-making period (Table 1), 
with relative humidity below $80 \%$, which allows the plant to reach a safe storage moisture content, with $20 \%$ DM, in less than 5 hours. Silva et al. (2011) obtained hay after 24 hours of sun exposure, which is much longer than the period found in the present study. These differences are related to the climatic factors in different regions and the morphological characteristics of the analyzed forage species.
Water loss occurs in three different stages after forage cutting. In the first stage, stomata are open, and water loss is rapid (Neres et al., 2010), which explains the dehydration peak in the first hour ( $\mathrm{H} 0$ to H1) of drying (Table 4). In the second stage, water loss occurs slowly via leaf cuticle during $\mathrm{H} 1$ and $\mathrm{H} 2$ with 2 hours of sun exposure. The third phase occurs between $\mathrm{H} 3$ and $\mathrm{H} 4$.

Table 4

Crude protein content of forage grass cultivars according to the drying time in the sun

\begin{tabular}{|c|c|c|c|c|c|c|c|c|}
\hline Cultivar & $\mathrm{H} 0$ & H1 & $\mathrm{H} 2$ & $\mathrm{H} 3$ & $\mathrm{H} 4$ & $\mathrm{R}^{2}$ & Equation & P-value \\
\hline Marandú & $21.3 \mathrm{~A}$ & $20.8 \mathrm{~A}$ & $19.9 \mathrm{~A}$ & $19.0 \mathrm{~B}$ & $18.1 \mathrm{~B}$ & 56.3 & $\mathrm{Y}=21.71-0.89 \mathrm{H}$ & $<0.01$ \\
\hline Xaraés & $18.2 \mathrm{~B}$ & $18.3 \mathrm{~B}$ & $18.4 \mathrm{~B}$ & $18.5 \mathrm{~B}$ & $18.6 \mathrm{~A}$ & & - & 0.40 \\
\hline Massai & $18.3 \mathrm{~B}$ & $18.4 \mathrm{~B}$ & $18.5 \mathrm{~B}$ & $18.6 \mathrm{~B}$ & $18.7 \mathrm{~A}$ & & - & 0.95 \\
\hline Paredão & $22.0 \mathrm{~A}$ & $21.5 \mathrm{~A}$ & $21.1 \mathrm{~A}$ & $20.6 \mathrm{~A}$ & $20.1 \mathrm{~A}$ & 42.7 & $\mathrm{Y}=22.07-0.48 \mathrm{H}$ & $<0.01$ \\
\hline Planaltina & $16.5 \mathrm{C}$ & $16.1 \mathrm{~B}$ & $15.8 \mathrm{C}$ & $15.5 \mathrm{C}$ & $15.2 \mathrm{C}$ & & - & 0.26 \\
\hline Tupã & $15.2 \mathrm{C}$ & $15.2 \mathrm{C}$ & $15.1 \mathrm{C}$ & $15.1 \mathrm{C}$ & $15.0 \mathrm{C}$ & & - & 0.72 \\
\hline SEM & & & 0.55 & & & & & \\
\hline P-value & & & $<0.01$ & & & & & \\
\hline
\end{tabular}

SEM: standard error of the mean. Values followed by the same letter in each column were not significantly different from each other using the Scott-Knott test at a level of significance of $5 \%$. *significant at $\mathrm{p}<0.05$ for the linear effect; ns, not significant at $\mathrm{p}<0.05$ for the linear effect.

The Massai cultivar presented the highest rate of water loss, and the average rate corresponded to an increase in $10.34 \%$ of DM per hour of sun exposure. The Tupã cultivar had the lowest rate (8.67\%).

These rates were higher than those obtained by Calixto et al. (2012) in star grass (Cynodon nlemfuensis), in which the average rate was $0.9 \%$ of DM per hour. These values were higher than those obtained by Silva et al. (2011), corresponding to $1.44-1.89 \%$ of DM per hour. The high rates obtained in the present study are explained by the high incidence of solar radiation in the region, high temperatures, and the low relative humidity during the hay-making period (Table 1).

There was a significant effect $(\mathrm{p}<0.01)$ of $\mathrm{CP}$ between the harvest times. The cultivar Paredão presented the highest $\mathrm{CP}$ content at all harvest times, whereas Tupã presented the lowest value (Table 4); $\mathrm{CP}$ was higher because of the genetic improvement in this cultivar (Mariani, Martins, Silva, Dalmolin, \& Brandão, 2018). The high CP content found in this study can be attributed to the constant nitrogen fertilization performed in the cultivation area. In addition, the higher number of leaves results in higher CP values in forage. Stems have typical CP values because of the intense deposition of lignin in their cell walls.

With respect to loss of $\mathrm{CP}$ during the drying period, Paredão and Marandú had a decreasing linear effect across the harvest periods, with 22.07 and $21.38 \pm 0.55 \%$ in $\mathrm{H} 0$ and 20.13 and $18.11 \pm$ $0.55 \%$ in $\mathrm{H} 4$, respectively. However, even with these losses, CP was higher in the cultivar Paredão. For the other cultivars, there was no significant effect of loss of CP during the hay-making period. 
The loss of CP in these cultivars is due to the lower LSR and reached $0.89 \pm 0.60 \%$ in Paredão and $0.88 \pm 0.60 \%$ in Marandú. The higher stem volume is related to the lower amount of plant sap, leading to higher losses in nutrient content (Paciullo, Gomide, Queiroz, \& Silva, 2001).

The Massai and Paredão cultivars presented the fastest rate of water loss among the evaluated cultivars, and consequently higher CP contents.

\section{References}

Alvares, C. A., Stape, J. L., Sentelhas, P. C., Moraes, G., Leonardo, J., \& Sparovek, G. (2013). Köppen's climate classification map for Brazil. Revista Meteorológica, 22(6), 711-728. doi: 10.1127/09412948.2013.0507

Calixto, M., Jr., Jobim, C. C., Cecato, U., Santos, G. T., \& Bumbieris, V. H., Jr. (2012). Curva de desidratação e composição químico-bromatológica do feno de grama-estrela (Cynodon nlemfuensis Vanderyst) em função do teor de umidade no enfardamento. Ciências Agrárias, 33(6), 2411-2422. doi: 10.5433/1679-0359.2012v33n6p2411

Dantas, C. C. O., \& Negrão, F. M. (2010). Fenação e ensilagem de plantas forrageiras. Pubvet, 4(40), 145, Art. 977. Recuperado de http://www.pubvet.com. br/uploads/d31a29e080c62f3186c5e8d0def59e8c. pdf

Detmann, E., Souza, M. A., Valadares, S. C., Fº, Queiroz, A. C., Berchielli, T. T., Saliba, E. O. S.,... Azevedo, J. A. G. (2012). Métodos para análise de alimentos - INCT - Ciência Animal. Visconde do Rio Branco: Suprema.

Ferreira,D. F.(2011). Sisvar: a computer statistical analysis system. Ciência e Agrotecnologia, 35(6), 1039-1042. doi: 10.1590 / S1413-7054.2011.0006.00001

Ferreira, D. J., Zanine, A. M., Lana, R. P., Ribeiro, M. D., Alves, G. R., \& Mantovani, H. C. (2014). Chemical composition and nutrient degradability in elephant grass silage inoculated with Streptococcus bovis isolated from the rumen. Anais da Academia Brasileira de Ciências, 86(1), 465-473. doi: 10.1590 / 0001-3765.2014.1123.12

Fonseca, D. M., \& Martuscello, J. A. (2010). Plantas forrageiras. Viçosa, MG: Ed. UFV.
Haddade, I. R., Vasquez, H. M., Detmann, E., Silva, J. F. C., Smith, R. B., \& Souza, P. M. (2005). Morfogênese e estruturação vegetativa em quatro genótipos de capim-elefante (Pennisetum purpureum Schum.). Arquivo Brasileiro de Medicina Veterinária e Zootecnia, 57(6), 811-819. doi: 10.1590/S01020935.2005.0006.00017

Instituto Nacional de Meteorologia. 2019. BDMEP Banco de Dados Meteorológicos para Ensino e Pesquisa. Recuperado de http:/www.inmet.gov.br/ portal/index.php? $\mathrm{r}=\mathrm{bdmep} / \mathrm{bdmep}$

Jobim, C. C., Nussio, L. G., Reis, R. A., \& Schmidt, P. (2007). Avanços metodológicos na avaliação da qualidade da forragem conservada. Revista Brasileira de Zootecnia, 36,(Supl.), 101-119. doi: 10.1590/S1516-3598.2007.0010.00013

Mariani, L., Martins, L. P., Silva, R. L. M., Dalmolin, V. R. F., \& Brandão, A. A. (2018). Produtividade da forrageira panicum maximum cv. $\mathrm{Mg} 12$ paredão submetido a diferentes níveis de adubação nitrogenada e de diferentes fontes. Connection Line, (18). doi: 10.18312 10.18312/1980-7341

Neres, M. A., \& Ames, J. P. (2015). Novos aspectos relacionados à produção de feno no Brasil. Scientia Agraria Paranaensis, 14(1), 10-17. doi: 10.18188/1983-1471/sap.v14n1p10-17

Neres, M. A., Castagnara, D. D., Mesquita, E. E., Jobim, C. C., Três, T. T., Oliveira, P. S. R., \& Oliveira, A. A. M. (2011). Production of tifton 85 hay overseeded with White oats or ryegrass. Revista Brasileira de Zootecnia, 40(8), 1638- 1644. doi: 10.1590/S15163598.2011.0008.00003

Neres, M. A., Castagnara, D. D., Mesquita, E. E., Zambom, M. A., Souza, L. C., Oliveira, P. S. R., \& Jobim, C. C. (2010). Production of alfalfa hay under different drying methods. Revista Brasileira de Zootecnia, 39(8), 1676-1683. doi: 10.1590/S15163598.2010.0008.00008

Oliveira, E. R., Monção, F. P., Araújo, G. A. M., Silva, L. H. X., Souza, C. V. M., Pedroso, F. W., \& Nascimento, F. A. (2016). Valor nutricional do colmo de gramíneas tropicais. Scientia Agraria Paranaensis, 15(3), 256264. doi: 10.1818/sap.v15i3.13558

Paciullo, D. S. C., Gomide, J. A., Queiroz, D. S., \& Silva, E. D. (2001). Composição química e digestibilidade in vitro de lâminas foliares e colmos de gramíneas forrageiras, em função do nível de inserção no perfilho, da idade e da estação de crescimento. Revista Brasileira de Zootecnia, 30(3), 964-974. doi: 10.1590/S1516-3598.2001.0008.00003 
Parsons, A. J., Johnson, I. R., \& Williams, J. H. H. (1988). Leaf age structre and canopy photosynthesis in rotationally and continuously grazed swards. Grass Forage Science, 43, 1-14. doi: 10.1111/j.13652494.1988.tb02136.

Pereira, G. F., Lima, P. O., Assis, L. C. S. L. C., \& Emerenciano, J. V., Neto. (2018). Nutrient intake, feeding behavior and performance of sheep fed hay of tropical grasses at different cutting intervals. Arquivo Brasileiro de Medicina Veterinária e Zootecnia, 70(3), 897-904. doi: 10.1590/1678-4162-9775

Pinho, R. M. A., Santos, E. M., Bezerra, H. F. C., Oliveira, J. S., Carvalho, G. G. P., Campos, F. S.,... Correia, R. M. (2013). Avaliação de fenos de capim-buffel colhido em diferentes alturas de corte. Revista Brasileira de Saúde e Produção Animal, Salvador, 14(3), 437-447. doi: 10.1590/S15199940.2013.0003.00004

Queiroz, D. S., Santana, S. S., Murça, T. B., Silva, E. A., Viana, M. C. M., \& Ruas, J. R. M. (2012). Cultivares e épocas de semeadura de milheto para produção de forragem. Revista Brasileira de Saúde e Produção Animal, 13(2), 318-329. doi: 10.1590/ S1519-9940.2012.0002.00003
Ribeiro, J. R. G. O., Teixeira, A. M., Velasco, F. O., Faria, W. G., Jr., Pereira, L. G. R., Chaves, A. V.,... Mcallister, T. A. (2014). Production, nutritional quality and in vitro methane production from Andropogon gayanus grass harvested at different maturities and preserved as hay or silage. AsianAustralasian Journal of Animal Science, 27(3), 330341. doi: 10.5713/ajas.2013.13161

Silva, E. B., Carneiro, M. S. S., Edvan, R. L., Coutinho, M. J. F., Rodrigues, C. T., Jr., \& Silva, M. S. M. (2011). Componentes morfológicos e curva de desidratação de gramíneas tropicais. Tecnologia \& Ciência Agropecuária, 5(3), 43-46. Recuperado de http://revistatca.pb.gov.br/edicoes/volume-05-2011/ volume-5-numero-3-setembro-2011/tca5308.pdf

Zanine, A. M., \& Diniz, D. (2006). Qualidade, conservação, método de cura, relação folha:colmo e consumo de feno de gramíneas tropicais. Revista Eletrônica de Veterinária, 7(9), 1-7. Recuperado de http://www.veterinaria.org/revistas/redvet/n101006. html 
